\title{
赤外分光分析の基礎と応用事例
}

浦 部 匡 史

\section{The Basics of Infrared Spectroscopy and Its Recent Applications}

Masashi URABE (Industrial Technology Center of Okayama Prefecture, 5301 Haga, Kita-ku, Okayama 701-1296, Japan) masashi_urabe@pref.okayama.lg.jp

Infrared spectroscopy (IR) is a useful tool to identify unknown substances. In addition, it is easy to handle even for beginners of chemical analysis. In this review, the basics of several recent applications of IR such as photoacoustic spectroscopy (PAS), micro-ATR imaging and AFM-IR are introduced.

(Received on September 13, 2017)

Key Words : Mid-Infrared Spectroscopy, FT-IR, ATR, Micro-ATR-Imaging, PAS, AFM-IR

\section{1. は じ め に}

赤外分光分析（infrared spectroscopy：IR）は, 対象物 について赤外光領域における波長毎の吸収挙動等の違いを 分光器を用いて調べる分析手法である. 現在の赤外分光器 の多くはフーリエ変換 fourier transform）方式であるた め, 通称FT-IR とも呼ばれる. FT-IR 装置の原理について は成書 ${ }^{1,2)}$ に委放る.

赤外分光分析は，有機物に関する情報を多く与えるた め, 異物分析などのトラブル対応から製品開発における材 料・組成分析まで幅広く用いられている。 また, 各種分析 手法の中でも，前処理・測定が容易かつ迅速な場合が多い ため，分析初心者が取組み易い手法でもある，本稿ではゴ ム分析初心者を対象とし, 中赤外領域での分析について, 前半で基礎的な解説を行い, 後半で近年のトピックについ て紹介を行う。

\section{2. 赤外吸収スペクトル}

有機物の赤外分光分析では，赤外光を波長ではなく, 1 $\mathrm{cm}$ の間にある波の数で表す波数（wavenumber）単位で 扱う場合が多い. 波数と波長の関係は波数 $\left(\mathrm{cm}^{-1}\right)=$ $10,000 /$ 波長 $(\mu \mathrm{m})$ の関係にある.
赤外分光分析においては, $4,000-400 \mathrm{~cm}^{-1}$ の波数を中 心とした中赤外の波数域がよく利用される ${ }^{3)}$. 横軸に波数 をとり, 縦軸に物質透過後の各波数での吸収の度合いを表 したものが，赤外透過吸収スペクトルである. Figure 1に 液状パラフィン（飽和炭化水素油）の赤外吸収スペクトル 例を示す。

横軸の波数は左から右に小さい值で表記する。吸収の度 合いは, 透過率 $T$ (transmittance), もしくは吸光度 $A$ (absorbance）として縦軸に示される. ある波数での物質透過 前の赤外光強度を $I_{0}$, 物質透過後の赤外光強度を $I$ とする と, 透過率 $T$ および吸光度 $A$ は, それぞれ次の式 (1), 式

（2）で表される。な押，透過率は通常百分率で示す.

$$
\begin{aligned}
& T=I / I_{0} \\
& A=-\log _{10} T
\end{aligned}
$$

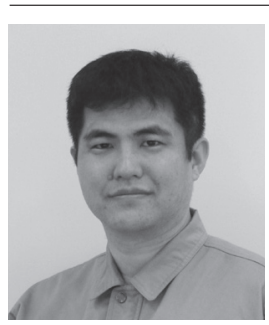

浦部 匡史；岡山県工業技術センター 研究 開発部 高分子グループ ( T 701-1296 岡山県 岡山市北区芳賀 5301）研究員. 博士 (工学). 平成 15 年, 京都大学大学院工学研究科分子工 学専攻博士後期課程修了。平成 18 年, 岡山県 工業技術センター 入所, 現在に至る. 専門 は, 高分子複合材料. 

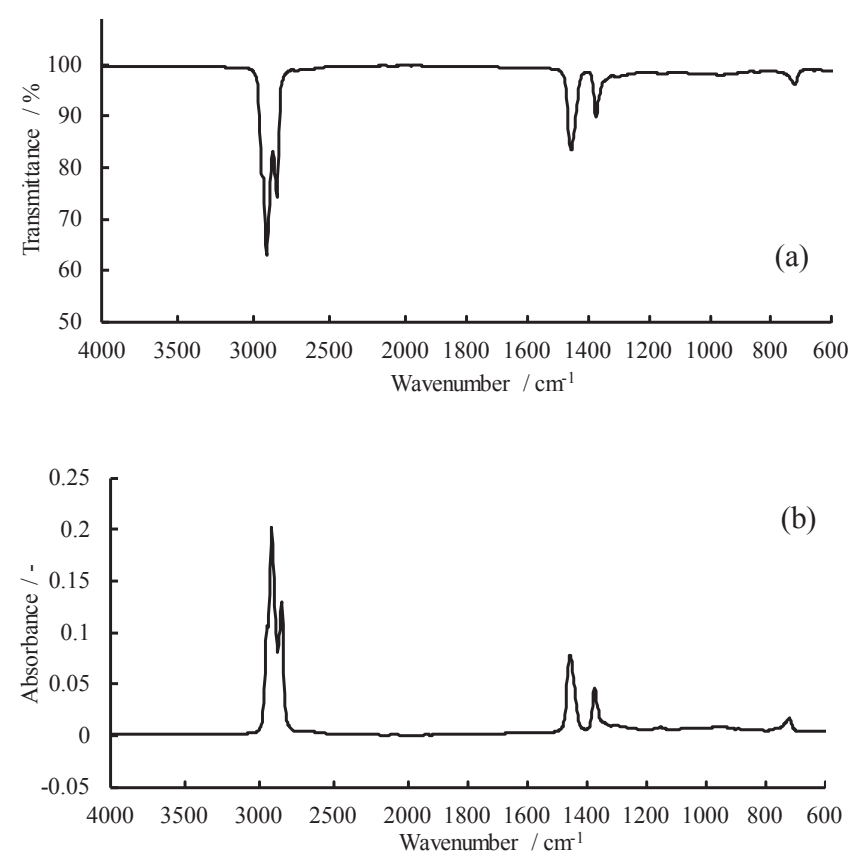

Figure 1 IR spectrum of liquid paraffin as a plot of (a) transmittance vs. wavenumber and (b) absorbance vs. wavenumber.

\section{3. 透過率と吸光度}

透過率 $T$ は, 試料による吸収の飽和や不足など, 測定 が適切な検出感度範囲で行われているかを直観的に判断し 易い。ただし，透過率 $T$ は試料厚さ・濃度とは比例しな い点には注意を要する，例えば，ある波数で透過率が 0.1 になるフィルムを $1 ， 2 ， 3$ 枚と重ねた場合，透過率は $0.1 ，$ $0.01 ， 0.001$ と指数的に減少する。一方, 吸光度 $A$ はそれぞ れ $1 ， 2 ， 3$ となり, 枚数（試料厚さ）と比例する.

吸光度 $A$ は吸光係数 $a$ と透過厚さ $b$ と濃度 $c$ との比例関 係にあるLambert-Beerの法則（式（3)）に従うため，物 質の組成比等を調べるなど，定量的な扱いを行う場合は吸 光度の利用が適切である.

$A=a b c$

定量分析については, JIS 規格にもSBRのミクロ構造の 分析例 ${ }^{4)}$ がある．混合物のスペクトルは各成分のスペクト ルに各分率を乗じた和になるため, 組成既知の試料につい て, 吸光度によるピークの高さもしくは面積から検量線を 作成すると良い。また，差スペクトルを取得することで， 未知の混合物についての情報を取得可能となるほか，ケモ メトリックスを利用した解析 ${ }^{5-7}$ も有用となる場合がある.

\section{4. 特性吸収帯と指紋領域}

赤外吸収スペクトルの具体例として, Figure 2 にエチレ ンプロピレンゴム $(\mathrm{EPDM})$ ，ポリスチレン $(\mathrm{PS})$ ，スチ レンブタジェンゴム（SBR）の測定例を示す.

Figure 1, Figure 2の物質の構成元素は全て Cと $\mathrm{H}$ み であり，スペクトルの違いは分子構造に由来するものであ
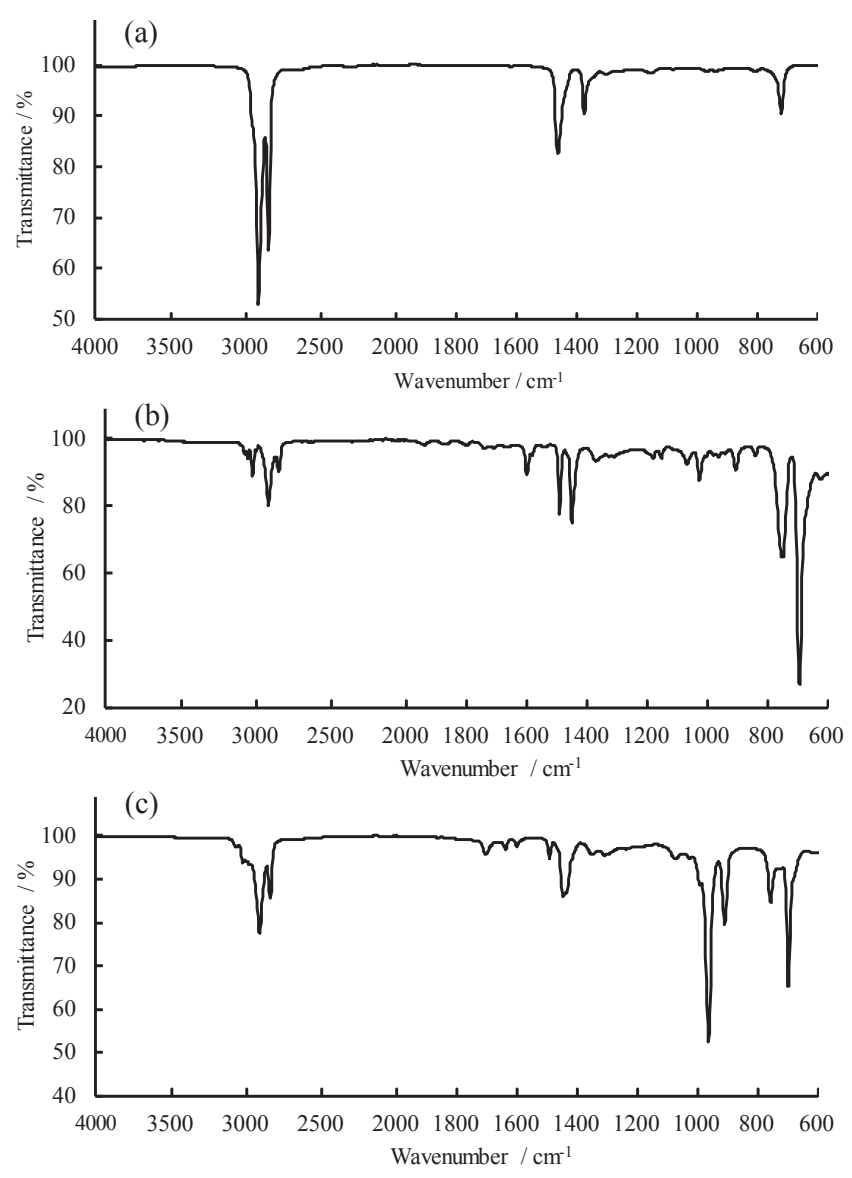

Figure 2 IR spectrum of (a) EPDM, (b) PS and (c) SBR

る(詳細は成書 ${ }^{1-2)} に$ 委ねるが, 中赤外領域の赤外光は 分子振動と同程度のエネルギーのため, 双極子モーメント が変化するような分子振動が赤外光と相互作用して吸収現 象を起こすことによる)。例えば, 分子構造の近い液状パ ラフィン (Figure 1) とEPDM (Figure 2a) の吸収スペ クトルは似ていることが分かる. 同じ官能基を持つPS (Figure 2b) とSBR（Figure 2c）にも類似の位置の吸収 ピークがあることが分かる．このように分子構造・官能基 に由来する吸収は類似の波数領域に現れる。

$1,500 \mathrm{~cm}^{-1}$ 以上の高波数領域には O-H, N-H, C-H, C $\equiv \mathrm{N}, \mathrm{C}=\mathrm{O}$ などの特定の官能基に由来する特性吸収带と 呼ばれる吸収が多く存在する。例えば，全てに観測される $2,900 \mathrm{~cm}^{-1}$ 付近のピークはC-H由来の吸収に帰属される. なお，吸収の大きさは様々に異なる。例えば $2,240 \mathrm{~cm}^{-1}$ 付近に現れる $\mathrm{C} \equiv \mathrm{N}$ の吸収は小さい場合が多く，初心者は 見逃し易いため注意したい.

赤外吸収スペクトルの吸収ピークがどの特性吸収带に帰 属するかを調べることで，試料の有する官能基が推定され る. 物質の性質は官能基に大きく依存するため, 試料特性 についてある程度の推定も可能となる。特性吸収帯への帰 属については専門書等 ${ }^{8)}$ が参考となる。 その他, 酸化に伴 って生じるカルボニル基 $(\mathrm{C}=\mathrm{O})$, 水酸基 $(-\mathrm{OH})$ の分析 等にもよく利用される。ただし, 劣化初期など濃度が低い 
場合にはX 線光電子分光法 (XPS) 等の別の分析手法が適 する場合もある.

次に $1,500 \mathrm{~cm}^{-1}$ 以下の領域は指紋領域とも呼ばれ, 官 能基由来の吸収と分子構造由来の吸収が複雑に現れるた め, 䚻属が難しくなる領域である.この指紋領域内にも PSやSBRなどの芳香環に由来する $700 \mathrm{~cm}^{-1}$ と $750 \mathrm{~cm}^{-1}$ 付近のピークなどのほか, $\mathrm{Si}-\mathrm{O}, \mathrm{C}-\mathrm{O}$, など官能基由来の 特徴的な吸収は多く出現する。 どの分子構造由来の吸収が どの領域に出現するかは, 専門書等 ${ }^{8)}$ が参考となるが, 実 際の解析においては教科書的な帰属には限界があるため, 各原材料や類似物, 比較対象物の測定結果等を併用して解 析を行うことが適切である.

\section{5. ゴムや有機化合物の赤外吸収スペクトルの例}

ゴムの赤外吸収スペクトルのピークの帰属については, JISK6230 P ISO4650に各種ゴムの赤外吸収スペクトルの 実例とピーク帰属例の記載があるため, 非常に参考にな る. JIS K6230については日本工業標準調査会のWEBサ イト ${ }^{9)}$ で無料閲覧が可能である（JISK6230の附属書表 A.1.2塩素化ポリエチレン (CM) の項の波数の帰属, 600 〜 $700 \mathrm{~cm}^{-1}$ はC-Cl, $720 \mathrm{~cm}^{-1}$ は-(CH)-と思われる).

その他の有機化合物のスペクトルについては, 国立研究 開発法人産業技術総合研究所の「有機化合物のスペクトル データベースシステム (SDBS) ${ }^{10)} 」 に$ 多く事例が掲載さ れている. 波数からの化合物検索も可能であるほか, 類似 構造物質を検索することでピークの帰属推定にも利用可能 である。

\section{6. 透 過 法}

赤外分光分析の測定について，基礎的な透過法から述べ る. 透過法は, 光源と分光器の間に試料を適切に設置し, ブランクとの比較測定をする手法である。ただし，透過光 は前述のとおり, 試料厚さや濃度により指数的に減少する ため，透過法では試料作製が問題となる場合が多い.

透過法の試料作製は，薄い試料を作製する手法と，測定 波数領域に赤外光吸収の少ない物質（臭化カリウム： $\mathrm{KBr}$ など）で濃度調整する手法に大別される。

薄い試料を作製する場合, ミクロトームでの切片作製 や，ダイヤモンドセルや $\mathrm{KBr}$ プレートに挟んでプレスす る手法, $\mathrm{KBr}, \mathrm{NaCl}$ ディスク間等に薄い液膜を作る方法 などがある．ただし，試料の厚さ次第では，赤外光の干渉 により透過スペクトルに正弦波的な変動が重畳する場合が ある，例をFigure 3 に示す。この場合は，試料の一部除 去後,再圧縮して薄膜化, または表面を少し粗化するか, 光軸に対して少し傾斜させると改善する場合がある.

次に, 濃度調整を行う場合には, $\mathrm{KBr}$ と試料をメノー乳 鉢などで混合して粉末化を行い，錠剤成型機で透明なディ

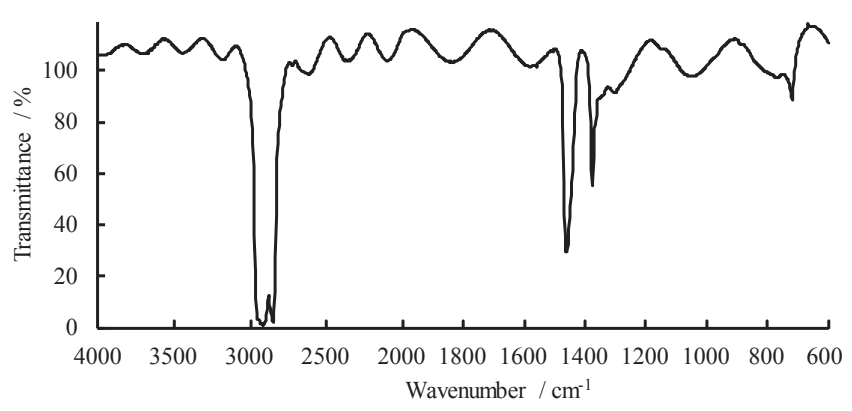

Figure 3 IR spectra of liquid paraffin with sinusoidal baseline caused by internal interference fringes.

スク化を行う。実際に試料測定を行い, 適切な透過率範囲 になるように濃度調整を行う必要がある。吸湿性の高い試 料等は, ヌジョール (nujol) と呼ばれる流動パラフィン の一種で希釈したのち, $\mathrm{KBr}$ プレートなどで挟んで測定す る場合もあるが, 解析時にはnujol由来の炭化水素系のピ ークを考慮する必要がある．前述のSDBSやその他のデー タベースにも nujol を用いて测定されたものがあるため, 他者の測定したデータの利用は試料調製・測定法などにも 注意すべきである。なお,カーボンブラックを多く含む黒 色ゴム等の測定は, 光の吸収が非常に強いため, 透過法で は測定が難しい場合が多い.

\section{A T R 法}

試料を薄膜化することなく，透過吸収スペクトルと類似 のスペクトルを得られるため, 近年普及が著しい手法が, ATR（attenuated total reflection）法である. ATR法で は光路中に高屈折率の ATRクリスタルを用いる点が特徴 である. Figure 4にATR法の原理図を示す.

試料はATRクリスタルに密着するように設置する. 高 屈折率のATRクリスタル側から低屈折率の試料側へ赤外 光を入射したとき, 臨界角以上では両者の界面で全反射現 象が生じる.この際, ATRクリスタル外側の極近傍にエ バネッセンス場（光が一部滲み出した状態）が形成される ため, 全反射した光はATRクリスタル近傍の試料の影響 を受けた光となる. 試料設置前後の全反射光を比較するこ とで, 透過吸収スペクトルと類似のスペクトルが得られる.

evanescent field

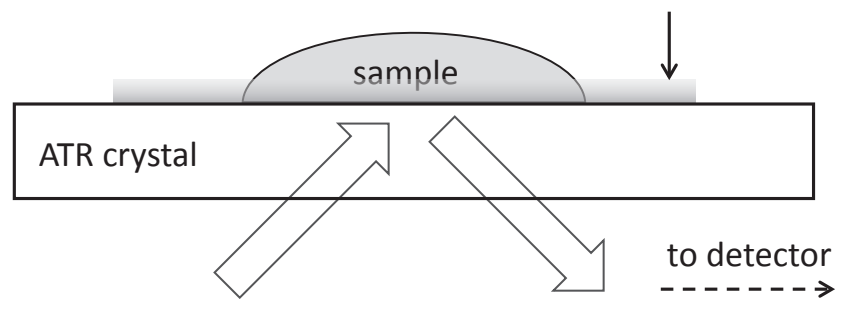

incident infrared beam

reflected infrared beam Figure 4 The principle of ATR. 
全反射光の滲みだし深さ（試料側への潜り込み深さ）

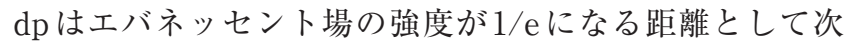
式（4）で表される ${ }^{11)}$.

$\mathrm{dp}=\lambda /\left(2 \pi n_{1}\right) \cdot\left(\sin ^{2} \theta-\left(n_{2} / n_{1}\right)^{2}\right)^{-1 / 2}$

$n_{1}$ : ATRクリスタルの屈折率, $n_{2}$ : 試料の屈折率,

$\lambda:$ 赤外光の波長, $\theta:$ 赤外光の入射角

潜り込み深さは波数やATRクリスタルの材質で異なる が, 約 $1 \mu \mathrm{m}$ 前後であり, 非常に薄い試料を測定する状態 に相当するため, 透過法のような薄片化をせずに測定が可 能となる，ただし，ATR法では透過法と比べ，低波数側 での吸収が相対的に大きくなる．また，ピーク形状にも歪 が生じる場合がある.

赤外光吸収が著しい黒色ゴムの分析においては，式（5） の入射角 $\theta$ を大きくするか，ATRクリスタルにダイヤモン ド $(n=2.4)$ よりも屈折率の高いゲルマニウム $(n=4.0)$ を利用することで，潜り込み深さがさらに小さくなるため 有利となる。

屈折率の異なるATRクリスタルを用い, カーボンブラ ックを50 wt\%（100 phr）添加した EPDMの測定例を Figure 5 に示す.

ATRクリスタルにダイヤモンドを用いた場合の Figure $5 \mathrm{a}$ では, カーボンブラックの高充继による透過率の低下 と, 試料とダイヤモンドの屈折率差の低減に伴い全反射条 件から外れる影響等により，元のゴム種は推定不能なスぺ クトルとなっている。一方，ゲルマニウムを用いた場合の Figure 5bでは，スペクトルは純EPDM（Figure 2a）と
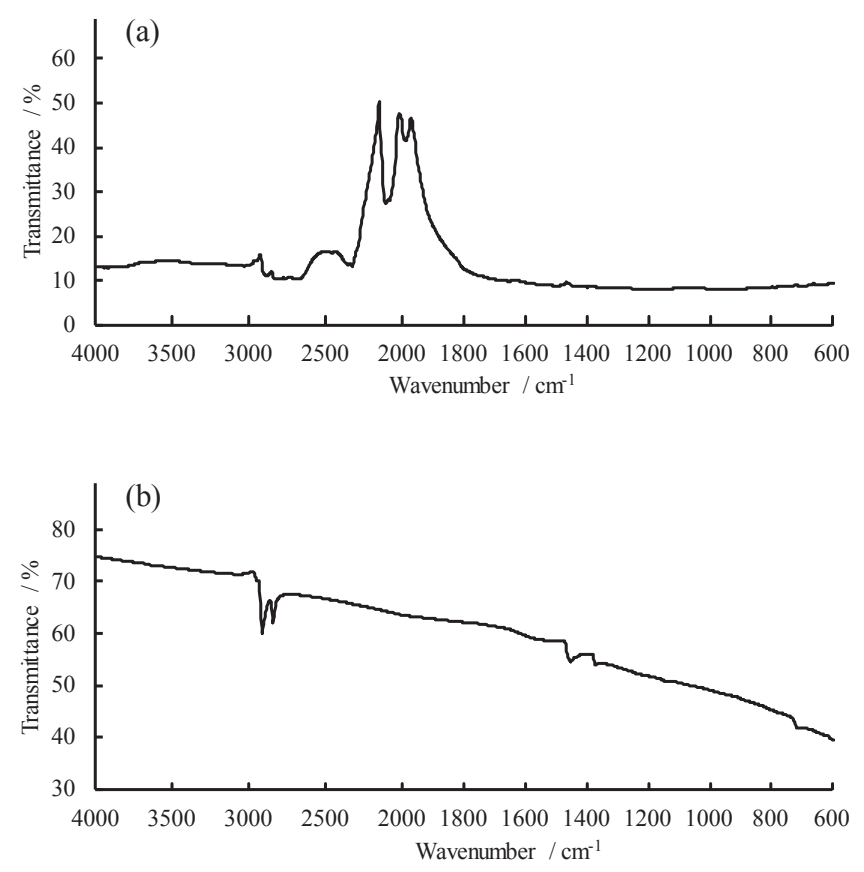

Figure 5 IR Spectra of carbon-filled EPDM (50 wt\% (100phr)) on (a) diamond ATR crystal and (b) germanium ATR crystal.
類似の吸収を示していることが十分に分かる.

\section{ATR 法の測定の実際}

ATR法の測定は，基本的に観察箇所をクリスタルに密 着させるだけで良いため, 数分でサンプリング〜測定〜解 析まで終わる場合も多い。測定の手順は，1）ATRクリス タルの清掃とバックグラウンド測定，2）試料をクリスタ ルに密着させて測定，3）試料を取り除き，場合によって はクリスタル転写物の測定を行う流れとなる.

液体試料もATRクリスタルや周囲の金属を侵さない場 合には，滴下するだけで測定が可能である，低濃度の液体 の場合は, 清浄なアルミ䇴等の上で乾燥させ, 乾固物を測 定すると良い場合もある.

初心者が失敗し易い注意点を例示すると，第一に，赤外 光の潜り込みの深さは非常に薄いため, 接触面の情報しか 得られていない点に注意が必要である. 特にゴム表面はブ ルーム・ブリード・離型剤・表面コート・手垢・埃などが ある場合が少なくない，材質を調べる場合には，清浄な切 断面を作製し，内部のスペクトルを取得することが望まし い.

第二に, ATRクリスタルとの密着不足・過剩である. 固体の場合, 適切な透過率となるように試料に適度に圧力 をかけ, ATRクリスタルと試料の接触面積を増やす必要 があるが，試料次第では高価な ATRクリスタルを破壊す る可能性もある。利用するATRクリスタルの硬さや試料 に金属塊が含まれていないかは注意を払うべきである．金 属板上の測定では，クリスタルへの密着性が悪いため，十 分な吸収が得られない場合も少なくない。この場合には後 述の反射法を検討するか, 凸状の ATRクリスタルの利用 で測定可能な場合がある。

第三に，測定時のATRクリスタルの污れに注意する必 要がある. 清掃が不十分だと次の測定の問題となる。ま た，清掃に有機溶剤等を利用した場合は，装置によっては 蒸気が光路中に漂い, 以降の測定時に問題となる場合もあ る. 清掃後にバッググラウンドを変えずに試し測定を行う と,清掃不足等の問題を判別可能である.

なお，ATR測定後，試料を外した直後に測定を行うと， 試料の表面付着物・ブリード物・離型剂などがクリスタル 転写物のスペクトルとして得られる。この転写物のスペク トル情報も有用となる場合が多い.

\section{9. 反 射法}

反射法については，物質表面での反射（正反射：Figure $6 \mathrm{a}$ ), 物質透過後の反射（透過反射, 反射吸収: Figure $6 \mathrm{~b})$, 反射・透過・屈折・散乱などが混合した拡散反射 (Figure 6c) に大別できる。それぞれに長所短所があるが, 破壊・接触できない試料や金属上の薄い試料については, 


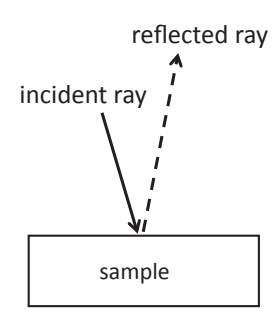

(a)

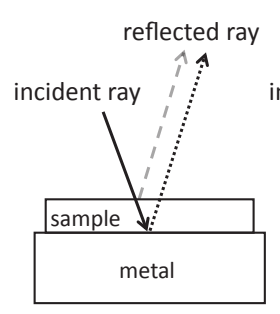

(b)

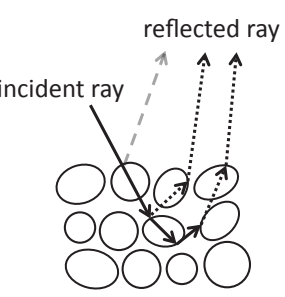

(c)
Figure 6 Schematic Diagram of (a) specular reflection and (b) reflection absorption and (c) diffuse reflection.
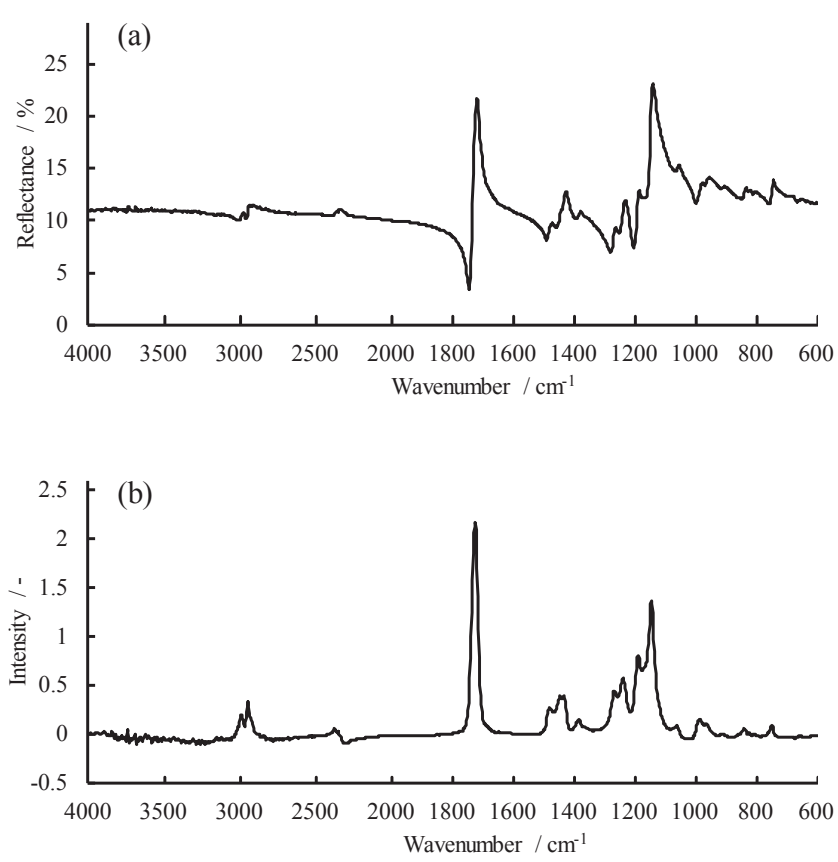

Figure 7 (a) Specular reflectance spectra of PMMA and (b) followed by Kramers-Krönig transformation.

反射法を試すと良い場合がある.

Figure 6aのような正反射，すなわち物質表面での反射 スペクトルは，吸収スペクトルと異なり，一次微分形に歪 んだスペクトル（Figure 7a）となる。この反射スペクト ルに, Kramers-Krönig変換を施すことで, 通常の吸収ス ペクトルに近い形（Figure 7b）に変換可能となる.

次に, Figure 6bのような物質透過後の反射光を調べる 反射吸収法は，吸収スペクトルと類似のスペクトルとな る.ただし，正反射成分と混合され，反射・透過複合の久 ペクトルが得られる場合もあるため，解析において問題と なる場合は少なくない，金属板上の試料が微量な場合に は, 試料に水平に近い角度で赤外光を入射させる高感度反 射法が有効な場合がある。

Figure $6 \mathrm{c}$ のような粉体試料の場合には，照射光は表面 反射や拡散・屈折・再反射を繰り返し, 拡散反射光として 検出される，拡散反射光は Kubelka-Munkの関係式で補正 を行うと，吸収スペクトルに似た形状のスペクトルに変換 される，拡散反射光の測定では， $\mathrm{KBr}$ などで希釈し，正反 射光を低減させると良いスペクトルが得やすい，拡散反射
法によるスペクトルは，粉体表面付近の情報が多く得られ る傾向がある。このため, 拡散反射法は表面処理された粉 体の表面化学構造の解析に有効である。 ただし, 検出感度 には限界があり，表面処理が少量の場合は検出されない場 合もあるため，既知試料による検証を行いながら分析を行 うことが望ましい.

\section{0. 顕 微 I R 法}

顕微IR 法は, 観察領域と測定対象が微小となるが, 前 述の各手法と基本は同じであり, 顕微透過法, 顕微 ATR 法，顕微反射法等がある。これらの測定手法の選択と試料 作製が分析の成否の多くを占める。例えば測定手法の選択 においては，分析対象が最表面にあるか，ATRクリス夕 ルに密着可能な位置にあるか, 対象物だけを採取可能であ るか等, 装置と試料の制約によって選択肢が変わる。 そし て測定手法を考慮して, 治具や周辺物由来の污れの付着・ 混入を避けるよう細心の注意を払い，適切な試料作製が達 成されたか否かで結果は大きく変わる場合がある.

通常の測定でも同じであるが，適切な分析のためには， 着手前の準備, 例えば実体顕微鏡などでの観察, 試料の詳細 と分析目的についての情報収集などが非常に重要となる ${ }^{12}$.

顕微 IRについての特有の問題としては，赤外光の利用 に起因する空間分解能の限界がある。例えば，空気中での 透過測定において，仮に測定波数範囲を $4,000-400 \mathrm{~cm}^{-1}$ とすると, これは $2.5-25 \mu \mathrm{m}$ の波長に対応し, 空間分解 能も同程度となるため, 多層フィルムや薄いコーティング などの分析で問題となる場合がある. 空間分解能を向上さ せる手法としては，ATRイメージング法がある，ATRイメ ージング法では片側がレンズ状になった専用のATRクリス タルを用いてイメージング測定を行うことで, 空気中での透 過法での測定よりも高い空間分解能での分析が可能 ${ }^{13,14)}$ と なる．または，傾斜切削法により試料を斜めに切削するこ とで, 深さ方向の情報を拡大して測定する手法 ${ }^{15,16)}$ もあ る. 後述の AFM-IRには空間分解能は劣るものの, 数百 $\mu \mathrm{m}$ 角程度の領域を $\mu \mathrm{m}$ オーダーでの物質の分散状態や劣 化の解析にも用いることが可能な手法である.

\section{P A S 法}

PAS（光音響分光法：photoacoustic spectroscopy）は, 非接触での測定を可能とする手法である.PASは試料に 断続的に赤外光を照射し, 光を吸収した試料が熱放出する 際に, 試料近傍の気体が断続的に膨張収縮する粗密波（音 波）を検出・解析することで, 吸収スペクトルと同等のデ 一夕を得ることが可能となる手法である，検出を工夫する と, 非接触で深さ方向の分析も可能となる. 従来は検出に マイクロフォンを利用していたが，近年はAFMと同様の カンチレバー利用技術により検出感度を向上させた機器も 
出現しており，ATRでの測定が困難な試料，例えば凹凸 の激しい試料や, 硬い材料の混ざっている試料, 非接触で 測定したい試料 ${ }^{17)}$ などについて，一定の効果があると期 待される.

\section{A F M - I R}

近年, $\mathrm{AFM}$ と組み合わせて, 赤外光の波長よりも大幅 に小さいnmオーダーの空間分解能で, 赤外吸収スペクト ルと同様のデータを得ることが可能な手法（AFM-IR）が 現れている．測定原理は，試料に波長可変のパルス赤外レ ーザーを照射し，吸収波長での試料の熱膨張を AFMで検 出するものと， カンチレバー先端での近接場光を利用する ものに大別される。レーザー照射も ATR状態に設置した 極薄試料に董面から照射するものや，試料上面からのレー ザー照射での測定を行うものなど，方式は様々に分かれ る. 空間分解能が試料厚さに影響を受ける場合もあるが, AFM の観察領域で物質の組成情報と分布図が得られるた め, 相分離構造やサブ $\mu \mathrm{m} \sim \mathrm{nm}$ オーダーでの物質の分散・ 分布状態，界面状態の解析事例も報告 ${ }^{18-21)}$ されてきてお り，今後の発展が期待される技術である。

\section{3. お わり に}

赤外分光分析は初心者でも取組み易い分析手法ではある が，赤外分光分析では金属，カーボンブラック，無機物の 一部など特徴的な吸収が見られないものも少なくない。例 えば酸化亜鉛とワックスから成る分散不良物を分析した場 合を考えると，酸化亜鉛の吸収は中赤外光領域にはほとん どないため, 少量のワックスのみのピーク情報が主とな り，赤外分光分析だけでは解釈を誤る場合もある．全ての 分析手法には必ず一長一短と種々の限界があるため, 適切 に組み合わせて分析を進めることが重要である。本稿の一 部でも, 赤外分光分析初心者の理解の一助になれば幸いで ある。

\section{References}

1 ) Furukawa, Y.; Takayanagi, M.; Hasegawa, T.: "Sekigai • Raman Bunkouhou”, Nihon Bunkou Gakkai Ed., Kodansha, Tokyo (2009)

2 ) Tasumi, M.: "Sekigai Bunkou Sokuteihou Kiso to Saishin Shuhou”, Nihon Bunkou Gakkai Ed., S. T. Japan, Tokyo (2012)

3 ) JIS K 0117:2017, General rules for infrared spectrophotometric analysis

4) JIS K 6239-2:2017, Styrene-butadiene rubber(SBR)-Determination of the microstructure of solution -polymerized SBR-Part 2: FTIR with ATR method
5 ) Hasegawa, T.; Ozaki, Y.: Bunseki Kagaku, 54, 1 (2005)

6 ) Hasegawa, T.: Nippon Setchaku Gakkaishi, 47, 430 (2011)

7 ) Tomii, S.; Ishizawa, H.; Koyama, S.; Morishima, M: Keisoku Jido Seigyo Gakkai Rombunshu, 50, 646 (2014)

8 ) Hesse, M., Meier, H., Zeeh, B.: Ichikawa, A., SV.: Nomura, M., Baba, A., Miura, M., Trans.: "Spectroscopic Methods in Organic Chemistry (2nd ed.)", Kagakudojin, Kyoto, Chapter2 (2010)

9 ) http://www.jisc.go.jp/

10) http://sdbs.db.aist.go.jp/

11) Ohnishi, A.: Nippon Setchaku Gakkaishi, 44, 174 (2008)

12) Ohtake, Y., Watanabe, T., Nakayama, K.: "Seihinchu no Ibutsu Konnyu to Sono Taisaku", Nikkan Kogyo Shimbunsha, Tokyo, p.5 (2012)

13) Okada, K.; Tsujii, T.; Yamada, K.; Nishimura, H.: Kobunshi Rombunshu, 71, 23 (2014)

14) Okada, K.; Tsujii, T.; Yamada, K.; Nishimura, H.: Kobunshi Rombunshu, 72, 149 (2015)

15) Sugiura, M.: Nippon Gomu Kyokaishi, 82, 161 (2009)

16) Esaki, Y., Tsuji, M.: Shikizai Kyokaishi, 83, 270 (2010)

17) Okuyama, M., Sato, M.: Seni Gakkaishi, 71, 6 (2015)

18) Urayama, N.:Shikizai Kyokaishi, 86, 225 (2013)

19) Suzuki, M.:Hyomen Gijutsu, 66, 590 (2015)

20) Izumi, Y., Banden, N., Matsuda, K.: Yosetsu Gakkaishi, 84, 591 (2015)

21) Higata, N.; Muraji, Y.; Takeda, M.: Nihon Gazo Gakkaishi, 56, 36 (2017)

\section{日本語表記参考文献}

1 ）古川行夫, 高柳正夫, 長谷川健 : 赤外・ラマン分光法, 日本分 光学会編, 講談社, 東京 (2009)

2 ) 田隅三生 : 赤外分光測定法 基礎と最新手法, 日本分光学会編, エス・ティ・ジャパン，東京 $(2012)$

3 ） JIS K 0117:2017，赤外分光分析通則

4) JIS K 6239-2:2017, 原料ゴム - 溶液重合 SBRのミクロ構造の求 め方（定量）－第2部：FTIR（ATR）法）

5 ）長谷川健, 尾崎幸洋：分析化学, 54, 1 (2005)

6 ）長谷川健：日本接着学会誌，47,430（2011）

7 ) 富井祥吾, 石澤広明, 児山祥平, 森島美佳 : 計測自動制御学会 論文集，50，646（2014）

8 ) Hesse, M., Meier, H., Zeeh, B. : 市川厚監修, 野村正勝, 馬場章夫，三浦雅博 訳 : 有機化学のためのスペクトル解析法 第 2 版, , 化学同人, 京都, 2 章 (2010)

11）大西晃宏：日本接着学会誌，44，174（2008）

12）大武義人, 渡邊智子, 仲山和海：製品中の異物混入とその対策 - 異物分析の手法と実例，日刊工業新聞社，東京 p.5（2010）

13）岡田きよみ, 辻井哲也, 山田和志, 西村寛之：高分子論文集, 71, $23(2014)$

14）岡田きよみ, 辻井哲也, 山田和志, 西村寛之：高分子論文集, 72, 149 (2015)

15）杉浦元保：日本ゴム協会誌，82，161（2009）

16）江崎泰雄，辻正男：色材協会誌，83，270（2010）

17）奥山誠義，佐藤昌憲：瀻維学会誌，71，6（2015）

18）浦山憲雄 : 色材協会誌，86，225（2013）

19）鈴木操：表面技術，66，590（2015）

20）泉由貴子，馬殿直樹，松田和大：溶接学会誌， 84, 591 (2015)

21）日下田成, 村司雄一, 竹田正明: 日本画像学会誌, 56, 36 (2017) 